Bangladesh J. Bot. 37(1): 21-26, 2008 (June)

\title{
INFLUENCE OF SEED AGEING ON GROWTH AND YIELD OF SOYBEAN
}

\author{
Rina Rani Saha and Wahida Sultana \\ Agronomy Division, Bangladesh Agricultural Research Institute, \\ Joydebpur, Gazipur-1701, Bangladesh
}

Key words: Seed ageing, Stand establishment, Crop growth rate, Seed yield

\begin{abstract}
Effect of seed ageing on stand establishment, growth and yield of three soybean varieties was studied. Treatments consisted of three varieties viz. Shohag, Bangladesh soybean 4 and BARIsoybean-5 with four levels of seed ageing viz. 20, 12, 8 and 2 months aged seed. Seed germination and field emergence percentage decreased but electrical conductivity of seed leachate increased with increasing seed age in all the soybean varieties. Irrespective of varieties, plants grown from 20 months aged seed accumulated more dry matter per plant but crop growth rate (CGR) were lower than the other ageing treatments. The highest dry matter accumulation and CGR were found in BARIsoybean-5 and lowest in Bangladesh soybean 4. Irrespective of varieties, crop grown from 2 months aged seed produced significantly the highest seed yield (1981 kg/ha) which was at par with the yield obtained from 8 months aged seed; and the lowest ( $811 \mathrm{~kg} / \mathrm{ha})$ was grown from 20 months aged seed. Among the varieties, significantly the highest seed yield (1615 kg/ha) was obtained from BARIsoybean-5 which was identical with that of Bangladesh soybean 4. Results further revealed that Bangladesh soybean 4 can be grown up to 12 months aged seed without significant reduction in seed yield.
\end{abstract}

\section{Introduction}

Quality seed is the prime factor for crop productivity. Seed quality, as measured by its vigour and viability, plays a major role in establishment of seedling as well as higher crop yield. A major cause of low vigour has been identified as seed ageing (Mathews 1980). In recent years, soybean has become an important oilseed crop in Bangladesh for increasing demand of poultry feed. Soybean seeds contain about 42 to $45 \%$ proteins as well as up to $22 \%$ edible oil (Mondal et al. 2002). However, non-availability of good quality seed remains one of the major constraints of soybean cultivation. Soybean seed germination and vigour potential is short lived as compared to other grain crops and it is often reduced prior to planting time (Byrd and Delouche 1971, Justice and Bass 1978, Nkang and Umoh 1996). Its seed is rapidly deteriorated by high temperature and high relative humidity during storage. Seed deterioration leads to reductions in seed quality, performance and stand establishment (McDonald 1999). No systematic studies have been carried out on seed quality aspects of soybean in Bangladesh. The present study was conducted with a view to evaluating the effect of seed ageing in determining stand establishment, growth and yield of three soybean varieties.

\section{Materials and Methods}

The experiment was conducted at the Central Research Farm, BARI, Joydebpur Gazipur during Rabi 2006-07. The experiment was laid out in a split plot design with three replications. Four levels of seed ageing viz. A1 (20 months), A2 (12 months), A3 (8 months) and A4 (2 months) were placed in the main plot and three varieties viz. $\mathrm{V}_{1}$ (Shohag), $\mathrm{V}_{2}$ (Bangladesh soybean 4) and $V_{3}$ (BARIsoybean-5) were placed in the subplot. Different aged seeds were collected from the harvest of rabi 2004-05, Kharif II 2005, Rabi 2005-06 and Kharif II 2006. Seeds were cleaned, properly dried (7.5 to 8\% moisture content) and stored in tin containers under ambient temperature for 20,12, 8 and 2 months. For germination percentage and electrical conductivity of seed leachate, the seeds were tested at laboratory prior to sowing. For electrical conductivity measurements, seed leachates were made by soaking 100 seeds in de-ionized water 
and kept for 24 hours. The size of each plot was $3 \mathrm{~m} \times 2.1 \mathrm{~m}$. Irrespective of ageing levels, seed rate for Shohag and BARIsoybean-5 (with larger seed) was $80 \mathrm{~kg} / \mathrm{ha}$ and for Bangladesh soybean 4 (with smaller seed) was $60 \mathrm{~kg} / \mathrm{ha}$. Seeds were sown with a spacing of $30 \mathrm{~cm} \times 5 \mathrm{~cm}$ on 11 December 2006. Field emergence percentage was counted at ten days after sowing (DAS). The experimental plots were fertilized @ 30-35-50-20 kg N-P-K-S/ha in the form of urea, triple super phosphate, muriate of potash and gypsum. Half of urea and full dose of other fertilizers were applied as basal. The rest of urea was applied at 39 days after sowing (DAS). Experimental field was irrigated, at 17, 37 and 80 DAS. Weeding and mulching were done at 30 DAS. Ripcord was sprayed to control hairy caterpillar and pod borer at ten days interval from vegetative to pod development stage. Five plants were collected randomly from each plot at different growth stages for growth analysis. Different plant parts were partitioned and oven dried and then weighed. At maturity, yield components were recorded from ten randomly selected plants from each plot and plot yield was recorded. Shohag and BARIsoybean-5 were harvested on 18 April, 2007 and Bangladesh soybean 4 was harvested on 22 April, 2007. Data were analyzed statistically and means were separated by DMRT.

\section{Results and Discussion}

Seed germination and field emergence percentage decreased and electrical conductivity of seed leachate increased with increasing seed age in all the three soybean varieties (Fig. 1). Decrease in germination of aged seeds might be due to either decline of alpha amylase activity and sugar content (Mitra et al. 1974) or denaturation of protein (Nautiyal et al. 1985). Under tropical conditions it has been established that soybean seed viability and vigour rapidly

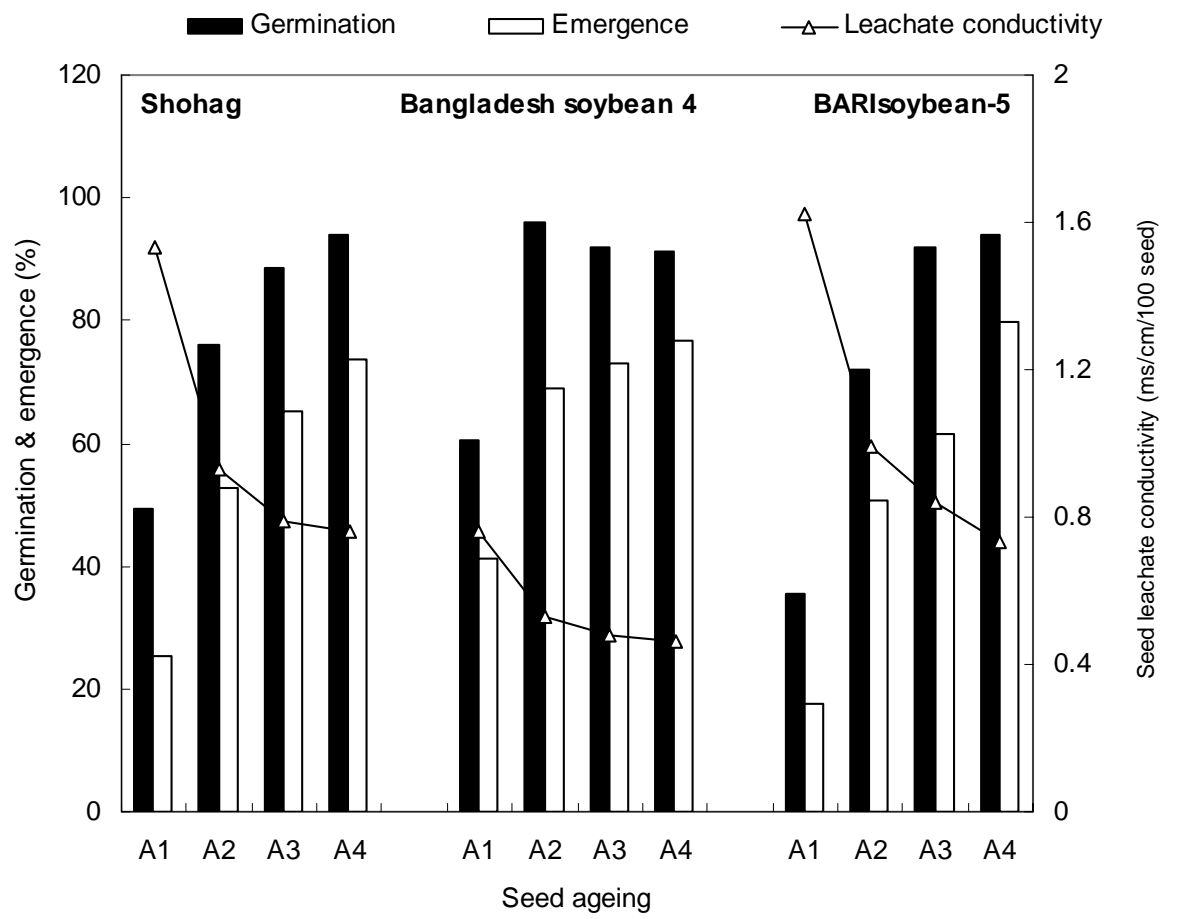

Fig. 1. Percentage of seed germination, field emergence and seed leachate conductivity in three soybean varieties as influenced by different seed ageing. 
reduced during storage at ambient temperatures (Nkang and Umoh 1996, Singh and Hatt 1986). On the other hand, electrical conductivity is related to the deterioration processes of seeds as degradation of cell membranes and leackage out of the cells (Delouche and Baskin 1973). Thus many researchers have used electrical conductivity test to indicate seed vigour (Normash and Chin 1991). Field emergence percentage was found positively correlated with the germination percentage $(r=0.91)$ and electrical conductivity of seed leachate was negatively correlated with germination percentage $(r=-0.80)$. Wilson and McDonald (1986) also assessed the possible reason for poor seed storability of soybean at the high levels of lipid peroxidation which led to the loss of cell membrane integrity. Among the varieties, Bangladesh soybean 4 showed lower seed leachate conductivity which also gave higher germination and field emergence percentages than the other two varieties. Varietal differences might be due to variation in genetic make up. Genotypic variations in soybean have also been reported for response to seed deterioration due to storage (Agrwal et al.1974, Ellis et al. 1982).

Total dry matter accumulation and its partitioning in different plant parts are presented in Fig. 2. The extent of dry matter accumulation and its distribution pattern showed considerable variation over growth stage in all the varieties irrespective of ageing level. Results revealed that all the varieties had a lag phase in early growth (vegetative to flowering stage) followed by a linear phase from pod development to maturity stage that might be due to rapid reproductive development. Plants grown from 20 months aged seed (A1) had more dry matter accumulation compared with the other three seed ageing. It might be due to more resource availability for individual plant because of lower plant stand per unit area (Table 1). This result is in agreement with that of Patel et al. (2003) observed that increased growth values in cowpea under lower plant stand per unit area were due to lower competition among plants for moisture, nutrient and sunlight. Shohag and BARIsoybean-5 accumulated more dry matter than Bangladesh soybean 4 irrespective of growth stages across the ageing treatment. Seed ageing considerably affected the crop growth rate (CGR) at different growth stages of soybean varieties. Although total dry matter accumulation in individual plant was higher in A1 but CGR was lower in A1 treatment at all the growth stages across the varieties. This might be due to lower plant stand per unit area. Bangladesh soybean 4 showed identical CGR in all the ageing levels but seed ageing adversely affected CGR in case of Shohag and BARIsoybean-5.

Seed yield and yield components of soybean differed significantly among the ageing levels. Number of pods/plant increased with increasing ageing period while plant population $/ \mathrm{m}^{2}$ decreased as seed ageing increased which ultimately resulted in decreasing seed yield (Table 1). Plant population $/ \mathrm{m}^{2}$ was positively correlated with field emergence percentage $(\mathrm{r}=0.90)$. The highest plant population $/ \mathrm{m}^{2}$ (55.26) and seed yield (1981 kg/ha) were recorded from A4 (plants from 2 months aged seed) and lowest from A1 treatment irrespective of varieties. Regardless of seed ageing, Bangladesh soybean 4 produced significantly higher number of plant population $/ \mathrm{m}^{2}$ and maximum pods/plant but 100-seed weight was lowest than the other two varieties (Table 2). The highest seed yield (1615 kg/ha) was recorded in BARIsoybean-5 and Bangladesh soybean 4 closely followed it. From the overall results it is observed that seed yield was mainly affected by plant population $/ \mathrm{m}^{2}$. A reasonable plant stand for a good seed harvest of Chinese fir (Cunninghamia lanceolata) was also established by Guan and Guan (1997). Results revealed that seed storage up to 12 months did not affect significantly seed yield in Bangladesh soybean 4 . Bhatia et al. (2002) were of opinion that soybean seed could be stored for about 8 to 9 months from its harvests. From the results of the present study it is concluded that Bangladesh soybean 4 could be stored up to 12 months and BARIsoybean- 5 up to 8 months under ambient condition after properly drying the seed for better crop yield. 

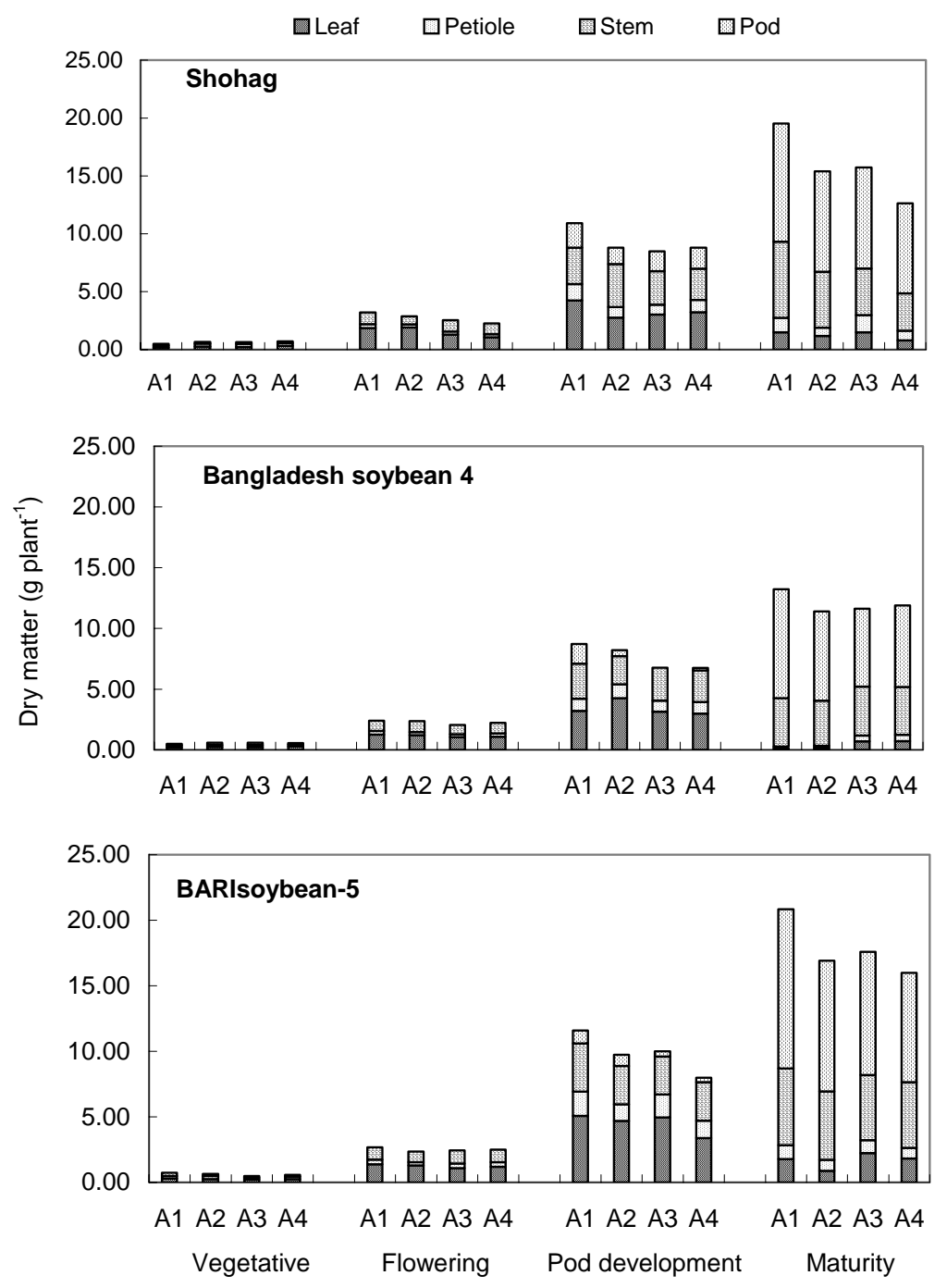

Fig. 2. Dry matter distribution in three soybean varieties as influenced by seed at different stages of growth.

Table 1. Yield and yield components of soybean as affected by seed ageing.

\begin{tabular}{lccccc}
\hline Treatment & $\begin{array}{c}\text { Population } / \mathrm{m}^{2} \\
\text { (No.) }\end{array}$ & $\begin{array}{c}\text { Pod/plant } \\
\text { (No.) }\end{array}$ & $\begin{array}{c}\text { Seed/pod } \\
\text { (No.) }\end{array}$ & $\begin{array}{c}100 \text { seed } \\
\text { weight (g) }\end{array}$ & $\begin{array}{c}\text { Seed yield } \\
\text { (kg/ha) }\end{array}$ \\
\hline A1* & $26.77 \mathrm{c}$ & $44.13 \mathrm{a}$ & 2.23 & 11.78 & $811.29 \mathrm{c}$ \\
A2 & $43.91 \mathrm{~b}$ & $30.06 \mathrm{~b}$ & 2.22 & 10.72 & $1530.45 \mathrm{~b}$ \\
A3 & $52.91 \mathrm{a}$ & $31.68 \mathrm{~b}$ & 2.34 & 11.18 & $1851.85 \mathrm{a}$ \\
A4 & $55.26 \mathrm{a}$ & $30.77 \mathrm{~b}$ & 2.30 & 10.68 & $1981.19 \mathrm{a}$ \\
CV (\%) & 11.08 & 10.14 & 6.94 & 9.31 & 12.24 \\
\hline
\end{tabular}

Means followed by same letter in a vertical column do not differ at $5 \%$ level. 


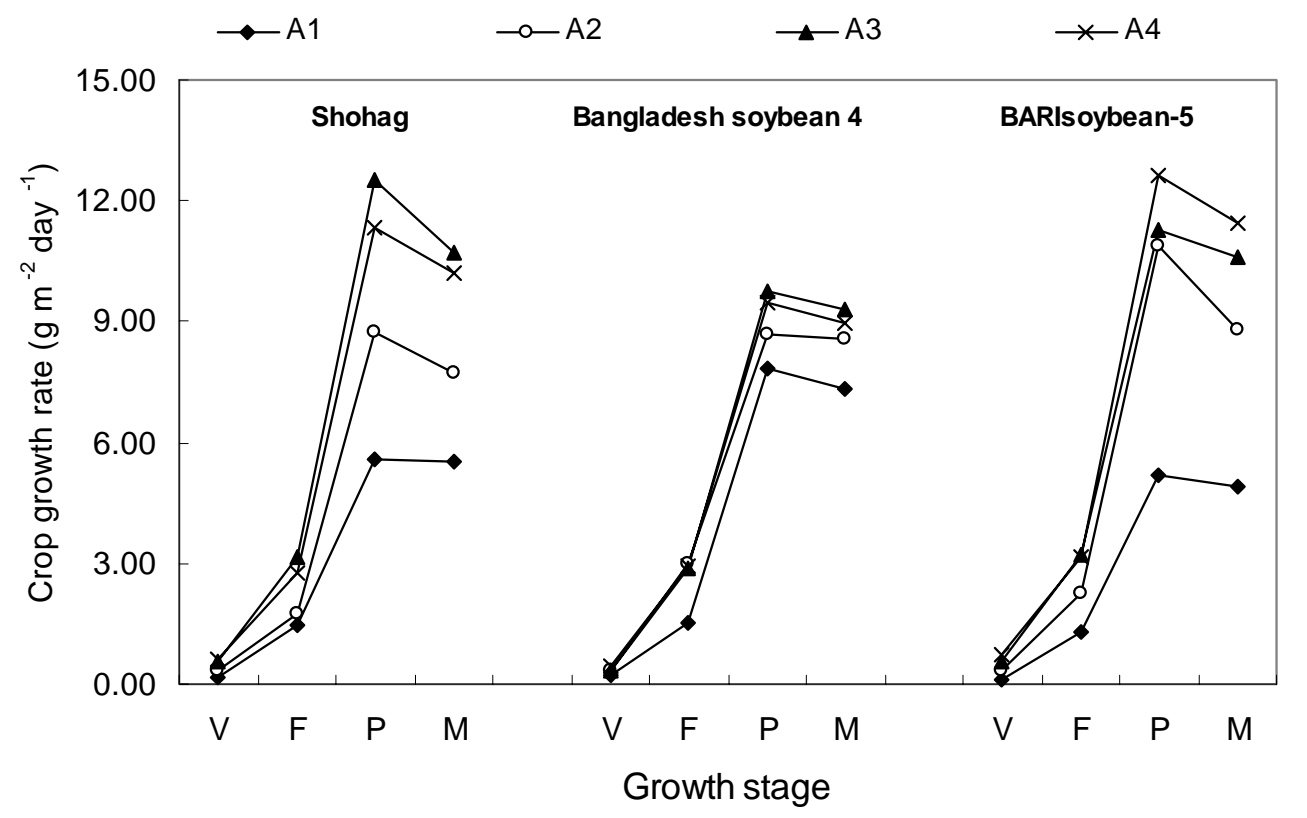

Fig. 3. Crop growth rate in three soybean varieties as influenced by different levels of seed ageing at vegetative $(\mathrm{V})$, flowering $(\mathrm{F})$, pod development $(\mathrm{P})$ and maturity stages of growth.

Table 2. Yield and yield components in different varieties of soybean.

\begin{tabular}{lccccc}
\hline Treatment & $\begin{array}{c}\text { Population } / \mathrm{m}^{2} \\
\text { (no.) }\end{array}$ & $\begin{array}{c}\text { Pod/plant } \\
\text { (no.) }\end{array}$ & $\begin{array}{c}\text { Seed/pod } \\
\text { (no.) }\end{array}$ & $\begin{array}{c}100 \text { seed } \\
\text { weight }(\mathrm{g})\end{array}$ & $\begin{array}{c}\text { Seed yield } \\
(\mathrm{kg} / \mathrm{ha})\end{array}$ \\
\hline $\mathrm{V}_{1}{ }^{*}$ & $41.26 \mathrm{~b}$ & $31.15 \mathrm{~b}$ & 2.15 & $12.69 \mathrm{a}$ & $1402.14 \mathrm{~b}$ \\
$\mathrm{~V}_{2}$ & $50.41 \mathrm{a}$ & $38.74 \mathrm{a}$ & 2.40 & $7.06 \mathrm{~b}$ & $1613.76 \mathrm{a}$ \\
$\mathrm{V}_{3}$ & $42.46 \mathrm{~b}$ & $32.59 \mathrm{~b}$ & 2.26 & $13.53 \mathrm{a}$ & $1615.21 \mathrm{a}$ \\
$\mathrm{CV}(\%)$ & 11.08 & 10.14 & 6.94 & 9.31 & 12.24 \\
\hline
\end{tabular}

Means followed by same letter in a vertical column do not differ at $5 \%$ level.

$* \mathrm{~V}_{1}=$ Shohag, $\mathrm{V}_{2}=$ Bangladesh soybean $4, \mathrm{~V}_{3}=$ BARIsoybean -5 .

\section{References}

Agrwal, V.K., O.V. Singh, P.N. Thapliyal and B.K. Malhotra. 1974. Control of purple stain disease of soybean. Indian J. Mycol. \& Pl. Pathol. 4: 1-4.

Byrd, H.W. and J.C. Delouche. 1971. Deterioration of soybean seeds in storage. Proc. Assoc. Off. Seed Anal. 61: 41-57.

Delouche, J.C. and C.C. Baskin. 1973. Accelerated ageing techniques for predicting the relative storability of seed lots. Seed Sci. \& Technol. 14: 427-452.

Ellis, R.H., K. Osci-Bonsu and E.H. Roberts. 1982. The influence of genotype, temperature and moisture on seed longevity in chickpea, cowpea and soybean. Ann. Bot. 50: 69-82. 
Guan, K. and Y. Guan. 1997. Analysis of seed yield composition in seed orchard of Chinese fir (Cunninghamia lanceolata). J. Zhejiang Forestry College. 14(3): 213-219.

Justice, O.I. and L.N. Bass. 1978. Principles and practices of seed storage. US Dept. of Agric. Hand Book. pp. 1-506.

Mathews, S. 1980. Controlled deterioration: a new vigour test for crop seeds. In: Seed production (Ed. P. D. Hebblethwaite), London, Butterworths. pp. 647-660.

McDonald, M.B. 1999. Seed deterioration: physiology, repair and assessment. Seed Sci. \& Tecnhol. 27: 177237.

Mitra, S., G. Ghose and S.M. Sircar. 1974. Physiological changes in rice seeds during loss of viability. Indian J. Agric. Sci. 44: 744-751.

Mondal, M.R.I., M.A. Wahab, M.S. Alam, M.M.U. Ahmed and F. Begum. 2002. Leaflet of BARI soybean 5. ORC. BARI, Joydebpur, Gazipur.

Nautiyal, A.R., A.P. Thapliyal and A.N. Purohit. 1985. Seed viability in Sal. IV. Protein changes : Accompanying loss of viability in Shorea robusta. Seed Sci. \& Technol. 13: 83-86.

Nkang, A. and E.O. Umoh. 1996. Six months storability of five soybean cultivars as influenced by stage of harvest, storage temperature and relative humidity. Seed Sci. \& Technol. 25: 93-99.

Normash, M.N. and H.F. Chin. 1991. Changes in germination, respiration and leachate conductivity during storage of Hevea seeds. Pertanika 14: 1-6.

Patel M.M., I.C. Patel, B.S. Patel and S.B.S. Tikka. 2003. Effect of row spacing and fertilizer doses on growth and yield attributing characters of cowpea [Vigna unguiculata (L.) Walp] under rainfed conditions. GAU Res. J. 28(1-2): 37-39.

Singh, S.R. and R.A. Hatt. 1986. Inheritance study of soybean seed storability using an accelerated ageing test. Field Crop Res. 13: 89-98.

Wilson, D.O. and McDonald M.B.1986. The lipid peroxidation model of seed deterioration. Seed Sci. \& Technol. 14: 269-300.

(Manuscript received on 2 October, 2007; revised on 16 March, 2008) 